\title{
PENYEBARAN UJARAN KEBENCIAN DALAM PERSFEKTIF HUKUM PIDANA ISLAM
}

\author{
Zainuddin Hasibuan \\ Fakultas Syariáh dan Hukum UIN Sunan Gunung Djati Bandung \\ Email: zainudinhasibuan@gmail.com
}

\begin{abstract}
Abstrak
Perkembangan teknologi informasi saat ini seperti pedang bermata dua, karena selain memberikan kontribusi bagi peningkatan kesejahteraan, kemajuan, dan peradaban manusia, sekaligus menjadi sarana efektif melakukan perbuatan melawan hukum. Permasalahan hukum yang sering kali dihadapi adalah ketika terkait dengan penyampaian informasi, komunikasi, dan/atau data secara elektronik. Kebebasan berpendapat seolah dibatasi oleh UU ITE tahun2008 ini, sehingga perlu adanya penjelasan atau kajian mengenai perbuatan ujaran kebencian yang dimaksud dalam UU ini dalam Pasal 28 ayat (2) Jo 45 ayat (2). Tinjauan Hukum Pidana Islam menggunakan dua istilah untuk tindak pidana yaitu jinayah dan jarimah, objek utama kajian fiqh jinayah yaitu al-rukn al-syar'i, al- rukn al-madi dan al-rukn aladabi, jika dikaitkan dengan materi pembahasan, dimana hal ini erat hubungannya dengan al-rukn al-madi, maka objek utama kajian fiqih jinayah meliputi tiga bagian pokok, yaitu Jarimah Qishahs /diyat, Hudud, dan Ta'zir. Maka perbuatan tindak pidana ujaran kebencian tergolong kepada jarimah ta'zir, yaitu jarimah yang tidak ditentukan bentuk ataupun sanksinya dalam nash.
\end{abstract}

\section{Kata Kunci: \\ Teknologi, Ujaran Kebencian, Pidana Islam}

\section{Pendahuluan}

Manusia semenjak lahir telah hidup dalam suatu masyarakat. Pada awalnya manusia berhubungan dengan orang tuanya, sebagai pendidik pertama dalam suatu keluarga. Meningkatnya usia seseorang maka pengetahuannya juga akan meningkat. Manusia membutuhkan proses komunikasi dalam setiap kehidupannya. Proses komunikasi adalah aktivitas yang diperlukan untuk mengadakan dan melakukan tindakan komunikatif, baik yang dilakukan oleh komunikator, komuni- 
kan, atau aktifitas penyampaian pesan, noise yang biasa saja terjadi dalam setiap tindakan komunikatif lainnya. ${ }^{1}$

Manusia berkomunikasi pada abad ini kebanyakan menggunakan pemanfaatan teknologi informasi, termasuk Indonesia. Menurut survey yang dilakukan oleh Asosiasi Penyelenggara Jaringan Internet (APJII) mengungkap bahwa lebih dari setengah penduduk Indonesia kini telah terhubung ke internet. Survei yang dilakukan sepanjang 2016 itu menemukan bahwa 132,7 juta orang Indonesia telah terhubungan ke internet. Sementara total penduduk Indonesia sendiri kurang lebih sebanyak 256,2 juta orang. Hasil ini mengindikasikan kenaikan 51.8 persen dibandingkan jumlah pengguna internet pada 2014 lalu. Survei yang dilakukan Asosiasi Penyelenggara Jaringan Internet Indonesia (APJII) pada 2014 hanya ada 88 juta pengguna internet. ${ }^{2}$

Teknologi informasi dapat merubah gaya hidup (lifestyle) bagi masyarakat di seluruh dunia tidak terkecuali di Indonesia juga terkena pengaruh perkembangan teknologi informasi di era globalisasi ini. Diikuti dengan jumlah penduduk Indonesia yang setiap tahun selalu bertambah populasi penduduknya karena angka kelahiran terus meningkat, sehingga pemanfaatan teknologi sangat diperlukan untuk menunjang perkerjaan sehari-hari. Pemanfaatan teknologi informasi telah menyebar luas ke berbagai macam kalangan anak-anak, mahasiswa, ibu rumah tangga, ekonomi atas sampai ekonomi bawah dan masih banyak yang lainnya yang dapat menggunakan situs jejaring sosial untuk kebutuhan masing-masing pengguna.

Teknologi informasi dan komunikasi juga menyebabkan hubungan dunia menjadi tanpa batas (borderless) dan telah menyebabkan perubahan sosial, ekonomi, dan budaya secara signifikan sedemikian cepat. Teknologi informasi saat ini menjadi pedang bermata dua karena selain memberikan kontribusi bagi peningkatan kesejahteraan, kemajuan, dan peradaban manusia, sekaligus menjadi sarana efektif melakukan perbuatan melawan hukum. Permasalahan hukum yang sering kali dihadapi adalah ketika terkait dengan penyampaian informasi, komunikasi, dan/atau data secara elektronik yang ber-

\footnotetext{
${ }^{1}$ Soerjono Soekanto, Pokok-Pokok Sosiologi Hukum, (Jakarta: PT Raja Grafindo Persada, 2001), hlm.1.

2 https://www.google.co.id/amp/isparmo.web.id/2016/11/21/data-statistik-penggunainternet-indonesia-2016/amp. Diakses pada tanggal 2 Oktober 2017 pukul 11:57 WIB
} 
muatan kebencian (hate speech) terhadap seseorang atau sekelompok orang yang dapat menimbulkan permusuhan. Akibat dari perkembangan tersebut, maka lambat laun, teknologi informasi dengan sendirinya juga telah mengubah perilaku masyarakat dari peradaban manusia secara global. ${ }^{3}$

Indonesia sebagai Negara hukum, memiliki peraturan yang mengatur perbuatan ujaran yang bermuatan kebencian dalam suatu bentuk perundang-undangan, yaitu Undang-undang Nomor 11 Tahun 2008 tentang Informasi dan Transaksi Elektronik (UUITE) dalam Pasal 28 ayat (2) yang menyebutkan:

"Setiap Orang dengan sengaja dan tanpa hak menyebarkan informasi yang ditujukan untuk menimbulkan rasa kebencian atau permusuhan individu dan/atau kelompok masyarakat tertentu berdasarkan atas suku, agama, ras, dan antar golongan (SARA)". ${ }^{4}$

Ujaran kebencian dalam Surat Edaran Kapolri No. SE/6/X/2015, bertujuan untuk menghasut dan menyulut kebencian terhadap individu dan/atau kelompok masyarakat dalam berbagai komunitas yang dibedakan dari aspek suku, agama, aliran keagamaan, keyakinan/kepercayaan, ras, antar golongan, warna kulit, etnis, gender, kaum difabel (cacat), orientasi seksual.

Pertimbangan lahirnya UU ITE ini terkait dengan perkembangan dan kemajuan teknologi informasi yang sedemikian pesat telah menyebabkan perubahan kegiatan kehidupan manusia yang secara langsung telah mempengaruhi lahirnya bentuk-bentuk perbuatan hukum baru. UU ITE diharapkan dapat mengatur dan mencegah masyarakat yang menggunakan media sosial dengan bijak, tanpa membatasi hak masyarakat dalam memperoleh ilmu maupun menyampaikan pendapatnya di muka umum.

Indonesia sebagai negara hukum telah menjamin kebebasan bagi setiap warga Negara Indonesia dalam menyampaikan pendapatnya sebagaimana tertuang dalam Undang-Undang Dasar Negara Republik Indonesia Tahun 1945 (UUD 1945) dalam Pasal 28 E ayat (3) yang berbunyi: "Setiap orang berhak atas kebebasan berserikta,

\footnotetext{
${ }^{3}$ Budi Suhariyanto, Tindak Pidana Teknologi Informasi (CYBERCRIME), (Jakarta: PT. Raja Grafindo Persada, 2014), hlm. 2.

${ }^{4}$ Undang-Undang R.I. No. 11 Tahun 2008 Tentang Informasi dan Data Transaksi Elektronik, (Yogjakarta: Pustaka Mahardika),hlm. 44.
} 
berkumpul, dan mengeluarkan pendapat". Sehingga perlu adanya penjelasan lebih lanjut tentang Pasal yang berkaitan dengan penyebaran ujaran kebencian sebagaimana dimaksud dalam Pasal 28 ayat (2) Undang-undang Nomor 11 Tahun 2008 tentang Informasi dan Transaksi Elektronik (UU ITE) agar tidak terjadi pengekangan hak berpendapat yang bisa melanggar hak azasi setiap orang dalam menyampaikan pendapatnya dan tidak menjadi Pasal yang bisa masuk kesemua jenis perbuatan yang berhubungan dengan kehormatan.

Islam merupakan agama yang sempurna. Artinya, mencakup seluruh aspek kepentingan manusia, baik mengenai urusan dunia maupun akhirat. Sebagaimana firman Allah SWT dalam al-Quran Surah al-Maidah ayat 3, yaitu:

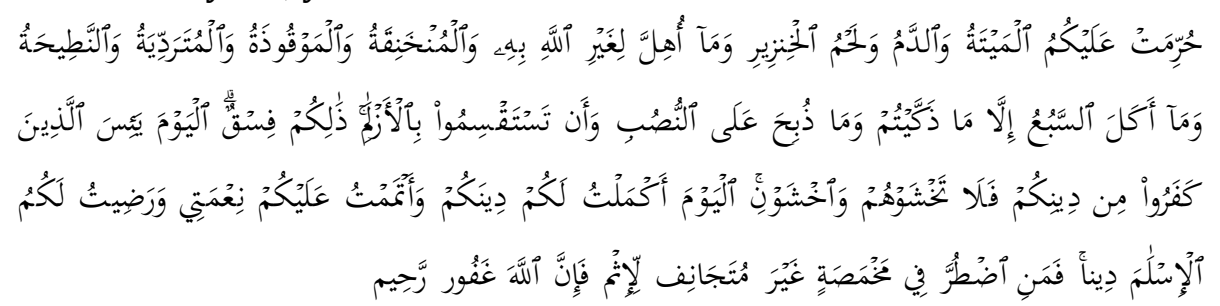

“....Pada hari ini telah kusempurnakan untuk kamu agamamu, dan telah $\mathrm{Ku}$ - cukupkan kepadamu nikmat-Ku, dan telah $\mathrm{Ku}-$ ridhai Islam sebagai agama bagimu, maka barang siapa terpaksa karena kelaparan tanpa sengaja berbuat dosa, sesungguhnya Allah Maha Pengampun lagi Maha Penyayang" (Q.S al- Maidah[5]:3) ${ }^{5}$

Makna dari nash yang tertuang dalam al-Quran Surah al-Maidah ayat 3, berarti semua yang berhubungan dengan urusan dunia, baik dari segi ekonomi, sosial, politik dan budaya juga didalamnya termasuk perbuatan penyebaran ujaran kebencian (hate speech) telah tercakup dalam Islam.

Islam sebagai agama yang rahmatan lil alamin yang mengajarkan hubungan ketuhanan dan kemanusiaan secara baik dan benar dengan berbagai macam syariat yang ada didalamnya sebagai hukum dalam melaksanakan sesuatu agar tidak bertentangan dengan larangan agama. Kemanusiaan menuntun untuk kehidupan manusia dalam berbagai aspek harus sesuai dengan syariat, hal ini bertujuan 
untuk melindungi harkat serta martabat manusia. Setiap perilaku yang merendahkan harkat dan martabat manusia baik secara pribadi maupun sebagai anggota masyarakat tentu dilarang oleh Allah SWT. ${ }^{6}$

Ujaran kebencian (hate speech) sangat erat kaitannya dengan penghinaan dan pencemaran nama baik dan merupakan pelanggaran yang menyangkut harkat dan martabat orang lain, yang berupa penghinaan biasa, fitnah/tuduhan melakukan perbuatan tertentu. Berita yang terkait dengan ujaran kebencian (hate speech) sangat besar pengaruhnya dan sangat jauh akibatnya, karena dapat menghancurkan reputasi, keluarga, karir, dan kehidupan di dalam masyarakat tentunya. Alquran Surah Al-Hujurat ayat 11, Allah SWT, berfirman :

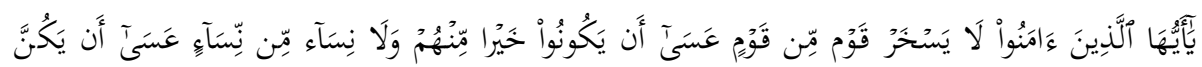

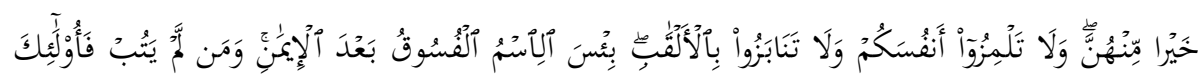
هُمُ ألظظلِّمُونَ

"Wahai orang-orang yang beriman! Janganlah suatu kamu mengolok-olok kaum yang lain, (karena) boleh jadi mereka (yang diperolok-olokan) lebih baik dari mereka (yang mengolokolok), dan jangan pula perempuan-perempuan (mengolokolokan) perempuan lain, (karena) boleh jadi perempuan (yang diolok- olokan) lebih baik dari pada perempuan (yang mengolok-olokan), janganlah kamu saling mencela satu sama lain, dan janganlah saling memanggil dengan gelar-gelar yang buruk. Seburuk-buruk panggilan adalah (panggilan) yang buruk (fasik) setelah beriman, dan barang siapa tidak bertaubat, maka mereka itulah orang-orang yang zalim" (Q.S. Al-Hujurat [49]:11)7

Aturan Islam hanya ada untuk kepentingan kesejahteraan umat manusia, bukan untuk kemudharatan mereka. Segala yang mendatangkan kebahagiaan bagi umat manusia adalah bagian dari ajaran Islam itu sendiri. Sementara segala sesuatu yang mendatangkan kemdharatan atau penderitaan bagi manusia merupakan hal yang bertentangan dengan ajaran Islam.

${ }^{6}$ Zainuddi Ali, Hukum Pidana Islam, (Jakarta; Sinar Grafika, 2007), hlm. 60

${ }^{7}$ Al-Qur'an dengan Tajwid Blok Warna diserta terjemahan, 2010, Op.Cit. 


\section{Tindak Pidana Ujaran Kebencian (HateSpeech) dalam UU ITE}

Terminologi Ujaran Kebencian dalam Kamus Besar Bahasa Indonesia (KBBI) terdiri dari dua suku kata yakni Ujar-an (perkataan yang diucapkan) dan benci, ke-benci-an (perasaan benci). Istilah ujaran kebencian (hate speech) sendiri merupakan suatu perbuatan komunikasi yang dilakukan oleh seseorang (individu) atau kelompok dalam bentuk provokasi, hasutan, ataupun hinaan kepada seseorang atau sekelompok orang yang dalam hal berbagai aspek sperti ras, warna kulit, gender, cacat, orientasi seksual, kewarganegaraan, agama dan lain sebagainya. Secara hukum, ujaran kebencian (hate speech) adalah perkataan, perilaku, tulisan ataupun pertunjukan yang dilarang karena dapat memicu terjadinya tindakan kekerasan dan sikap prasangka, baik dari pihak pelaku pernyataan tersebut ataupun korban dari tindak tersebut. 8

Istilah ujaran kebencian (hate speech) dalam arti hukum yaitu tindakan komunikasi yang dilakukan oleh suatu individu atau kelompok dalam bentuk provokasi, hasutan, ataupun hinaan kepada individu atau kelompok yang lain dalam hal berbagai aspek seperti ras, warna kulit, etnis, gender, kewarganegaraan, agama, dan lain-lain.

Defenisi dari penyebaran ujaran kebencian (hate speech) dalam konvensi internasional dikaitkan dengan hak atas kebebasan berpendapat. Larangan ujaran kebencian (hate speech) merupakan pembatasan dari berpendapat. Defenisi mengenai ujaran kebencian (hate speech) baru disinggung dalam International Convention on the Elimination of all Forms of Racial Discrimination (ICERD) di mana dalam Pasal 4 huruf a ICERD menyinggung mengenai ruang lingkup ujaran kebencian yang meliputi penyebarluasan gagasan berdasarkan superioritas ras atau kebencian rasial, serta semua tindakan kekerasan atau hasutan terhadap tindakan diskriminasi terhadap rasa tau kelompok orang dengan warna lain atau asal etnis. ${ }^{9}$

Pengertian ujaran kebencian (hate speech) dapat dipahami dari beberapa pendapat menurut para ahli, sebagai berikut:10

1. Anne Weber: persoalan kompleks hampir di semua negara,

\footnotetext{
${ }^{8}$ Sutan Remy Syahdeini, Kejahatan dan Tindak Pidana Komputer, (Jakarta: Pustaka Utama Grafiti, 2009), hlm 38

Bus sines-law.bi nus.a c.id/2017/ 07/ 25tum pang -tin dih-lingkup-dan-ketentua n-pidana mengenai-ujaran-kebencian-di-indonesia/diakses padaTanggal 19 Februari2018Pukul 13:40 WIB

${ }^{10}$ www.investigasibhayangkara.com/pengertian-hate-speech-hukum/diakses pada Tanggal 19Februari 2018 Pukul 14:12 WIB
} 
juga Indonesia dan merumuskan konsep ini, saat ini tidak ada defenisi hate speech yang bisa secara universal.

2. Margaret Brown L-Sica dan Jeffrey Beall: Mewujudkan dalam banyak tindakan seperti, menghina, menyakiti, atau merendahkan kelompok minoritas tertentu dengan berbagai macam sebab, baik berdasarkan ras, gender, etnis, kecacatan, kebangsaan, agama, oriantasi seksual, maupun karakteristik lain.

3. Jhon K Roth: tindakan kejahatan dan ucapan menyinggung diarahkan kepada individu karena ras, etnisitas, agama, orientasi seksual, kelompok afiliasi lain.

4. Kathelen Mahoney membagi hate speech ke dalam beberapa jenis, yaitu religious hate speech, pencemaran budaya, pencemaran ekonomi dan eksentansil atau genosida, pidato kebencian agama memiliki ciri yaitu menyatakan bahwa suatu agama berbahaya bagi agama lain, sehingga mempromosikan penghancuran, contohnya penyerangan atau penghancuran tempat ibadah.

Pendapat para ahli tentang hate speech berbeda dan bermacam-macam defenisi dan rumusan konsepnya. sampai sekarang ini belum ada pengertian ujaran kebencian (hate speech) yang digunakan secara universal, begitu pula defenisi secara hukum atas. Kata hate speech dalam Bahasa Indonesia disepadankan dengan kata ujaran kebencian dan merupakan pembatasan akan kebebasan berpendapat yang dijamin dalam Undang-Undang Dasar (UUD 1945).

Negara di seluruh dunia hampir seluruhnya memiliki undangundang tentang ujaran kebencian (hate speech). Di Indonesia ketentuan mengenai larangan ujaran kebencian (hate speech) terhadap seseorang atau sekelompok ataupun lembaga diatur dala m UU I T E . Selain itu, ditemukan pula dalam Pasal 156, Pasal 157, Pasal 310, Pasal 311 KUHP, kemudian Pasal 16 Undang-undang No. 40 Tahun 2008 tentang Penghapusan Diskriminasi Rasa dan Etnis, dan Surat Edaran Kapolri No: SE/06/X/2015.

Pasal 1 ayat (3) UUD 1945, secara tegas menyatakan bahwa negara Indonesia adalah Negara hukum. Sebagai negara hukum, maka seluruh aspek dalam bidang kemasyarakatan, kebangsaan, dan 
kenegaraan termasuk pemerintahan harus senantiasa berdasarkan atas hukum.

Dasar atau rujukan yang dijadikan untuk membentuk undangundang yang mengatur tentang informasi dan transaksi elektronik terdapat dalam konsideran UU ITE, yaitu:

a. Bahwa pembangunan nasional adalah suatu proses yang berkelanjutan yang hasrus senantiasa tanggap terhadap berbagai dinamika yang terjadi di masyarakat;

b. Bahwa globalisasi informasi telah menempatkan Indonesia sebagai bagian dari masyarakat informasi sehingga mengharuskan dibentuknya pengaturan mengenai pengelolaan Infomasi dan Transaksi Elektronik di tingkat nasional sehingga pembangunan teknologi informasi dapat dilakukan secara optimal, merata, dan menyebar ke seluruh lapisan masyarakat guna mencerdaskan kehidupan bangsa;

c. Bahwa perkembangan dan kemajuan teknologi informasi yang demikian cepat telah menyebabkan perubahan kegiatan kehidupan manusia dalam berbagai bidang yang secara langsung telah mempengaruhi lahirnya bentuk- bentuk perbuatan hukum baru;

d. Bahwa penggunaan dan pemanfaatan teknologi informasi harus terus dikembangkan untuk menjaga, memelihara, dan memperkukuh persatuan dan kesatuan nasional berdasarkan Peraturan Perundang-undangan demi kepentingan nasional;

e. Bahwa pemanfaatan teknologi informasi berperan penting dalam perdagangan dan pertumbuhan perekonomian nasional untuk mewujudkan kesejahteraan masyarakat;

f. Bahwa pemerintah perlu mendukung pengembangan teknologi informasi melalui infrastruktur hukum dan pengaturannya sehingga pemanfaatan teknologi informasi dilakukan secara aman untuk mencegah penyalahgunaannya dengan memperhatikan nilai-nilai agama dan sosial budaya masyarakat Indonesia

Lahirnya UU ITE merupakan ketentuan atau peraturan perundang-undangan yang menjadi perluasan dari ketentuan yang ada di dalam KUHP yaitu Pasal 103 yang berbunyi "Ketentuan-ketentuan dalam Bab I sampai Bab VIII buku ini juga berlaku bagi perbuatan yang 
oleh ketentuan perundang-undangan lainnya diancam dengan pidana, kecuali jika oleh undang-undang ditentukan lain"11

UU ITE mulai dirancang pada bulan Maret Tahun 2003 oleh Kementerian Negara Komunikasi dan Informasi (Kominfo), pada mulanya Rancangan Undang-undang (RUU) Informasi dan Transaksi Elektronik (ITE) diberi nama Undang-undang Informasi, Komunikasi dan Transaksi Elektronik oleh Depatermen Perhubungan, Depatermen Perdagangan, serta bekerja sama dengan Tim dari Universitas yang ada di Indonesia, yaitu Universitas Padjajaran (Unpad), Institut Teknologi Bandung (ITB), dan Universitas Indonesia (UI).

Tanggal 5 September 2005 secara resmi Presiden Susilo Bambang Yudhoyono menyampaikan RUU ITE kepada DPR melalu surat No.R/70/Pres/9/2005. Menunjuk Dr. Sofyan Djalil (Menteri Komunikasi dan Informatika) dan Momammad Andi Mattalata (Menteri Hukum dan Hak Azasi Manusia) sebagai wakil pemerintah di DPR RI. Dalam rangka pembahasan RUU ITE Departemen Komunikasi dan Informasi membentuk Tim Antar Departemen (TAD) melalui Keputusan Menteri Komunikasi dan Informatika No. 83/KEP/ M. KOM INFO/10/2005 tanggal 24 Oktober 2005 yang kemudian disempurnakan dengan Keputusan Menteri No. 10/KEP/M.Kominfo/01/2007 tanggal 23 Januari 2007.

Tugas Tim Antar Departemen antara lain menyiapkan bahan, referensi, dan mengikuti pembahasan RUU ITE di DPR RI. Dewan Perwakilan Rakyat (DPR) merespon Surat Presiden dengan membentuk Panitia Khusus (Pansus) RUU ITE yang beranggotakan 50 orang dari 10 Fraksi di DPR RI dalam rangka menyusun Daftar Inventaris Masalah (DIM) atas draf RUU ITE yang disampaikan Pemerintah. Pada tanggal 24 Januari 2007 sampai dengan 6 Juni 2007 Pansus DPR RI dengan Pemerintah membahas DIM RUU ITE. Tanggal 29 Juni 2007 sampai dengan 31 Januari 2008 pembahasan RUU ITE dalam tahapan pembentukan dunia kerja (Panja).

Sedangkan pembahasan RUU ITE tahap Tim Perumus (Timus) dan Tim Sinkronisasi (Timsin) yang berlangsung sejak tanggal 13 Februari 2008 sampai dengan 13 Maret 2008. Pada tanggal 18 Maret 2008 merupakan naskah akhir UU ITE dibawa ke tingkat II sebagai

${ }^{11}$ Moeljatno, Kitab Undang-Undang Hukum Pidana (KUHP), (Jakarta: Bumi Aksara, 2014), 
pengambilan keputusan. Pada tanggal 25 Maret 2008, 10 Fraksi menyetujui RUU ITE ditetapkan menjadi Undang-Undang. Selanjutnya Presiden Susilo Bambang Yudhoyono menandatangani naskah UU ITE menjadi Undang-Undang Republik Indonesia Nomor 11 Tahun 2008 tentang Informasi dan Transaksi Elektronik, dan dimuat dalam Lembaran Negara Nomor 58 Tahun 2008.

Perbuatan ujaran kebencian (hate speech) yang dimaksud dalam UU ITE diatur dalam Bab VII Pasal 28 ayat (2) dan dalam Bab XI Pasal 45 ayat (2). Perbuatan yang termasuk ke dalam ujaran kebencian (hate speech) dalam pasal ini adalah:

Pasal 28 ayat (2): "Setiap orang dengan sengaja dan tanpa hak menyebarkan informasi yang ditujukan untuk menimbulkan rasa kebencian atau permusuhan individu dan/atau kelompok masyarakat tertentu berdasarkan atas suku, agama, ras, dan antargolongan (SARA)".

\section{Tinjauan Hukum Pidana Islam terhadap Tindak Pidana Ujaran Kebencian (Hate Speech)}

Ujaran kebencian (hate speech) dalam hukum pidana Islam merupakan suatu perbuatan yang dilarang oleh aturan-aturan hidup dalam Islam, Allah SWT mengharamkan perbuatan-perbuatan yang menyentuh kehormatan seseorang, dan ini juga merupakan kesepakatan para ulama. Bahwa perbuatan yang mencela orang lain itu adalah haram. Ujaran kebencian (hate speech) sangat erat kaitannya dengan pencemaran nama baik. Karena dampak yang ditimbulkan dari penyebaran ujaran kebencian (hate speech) akan merendahkan dan mencederai nama baik seseorang. Al-Ghazali berpendapat bahwa, perbuatan yang dilakukan oleh seseorang berupa pencemaran nama baik adalah menghina atau merendahkan orang lain di depan manusia atau di depan umum. ${ }^{12}$

Imam Ghazali, menjelaskan bahwa buruk sangka (suudzhan) adalah haram, sebagaimana ucapan yang buruk. Keharaman berburuk sangka itu seperti haramnya membicarakan keburukan seseorang kepada orang lain. Oleh karena itu, tidak diperbolehkan juga membicarakan keburukan seseorang kepada diri sendiri atau di dalam

${ }^{12}$ Abdul Hamid Al-Ghazali, Ihyaul Ulumuddin, (Ciputat: Lentera Hati, 2003), hlm. 379. 
hati, sehingga kita berprasangka buruk tentang seseorang. Al-Ghazali maksudkan adalah keyakinan hati bahwa suatu keburukan tertentu terdapat di dalam diri orang lain. Bisikan hati yang hanya terlintas sedikit saja, maka itu di maafkan. Sedangkan, yang dilarang adalah berprasangka buruk, dimana persangkaan adalah sesuatu yang diyakini di dalam hati.

Imam Al-Qurthubi menerangkan bahwasanya buruk sangka itu adalah melemparkan tuduhan kepada seseorang tanpa dasar yang benar. Yaitu seperti menuduh orang lain melakukan perbuatan jahat, akan tetapi tanpa disertai dengan bukti-bukti yang membenarkan tuduhan tersebut. Tidaklah semata-mata Rasulullah SAW melarang umatnya dari suatu perbautan tertentu, kecuali karena perbuatan tersebut bias berdampak buruk. Hal itu sama saja dengan fitnah yang merupakan bagian dari ujaran kebencian. KH. Nasruddin Umar menerangkan bahwa ujaran kebencian itu adalah fitnah, menghasut, dan penyebaran berita bohong. Pertama adalah penghinaan, kedua berbuat tidak menyenangkan dan yang ketiga adalah provokasi. Hal ini bisa dipidana. 13

Ujaran kebencian (hate speech), secara sederhana merupakan bentuk perbuatan yang mengandung kebencian, baik lisan maupun tulisan. Pelaku ujaran kebencian (hate speech) seringkali terangterangan melakukan hasutan untuk mecapai kepentingannya, dengan menggunakan kata-kata yang tidak seharusnya atau tidak pantas dan menimbulkan fitnah. Allah SWT telah jelas melarang umatnya manusia untuk tidak mengolok-olokan satu dengan yang lain, seperti mencela dan menghina mereka. Sebagaimana firman Allah SWT :

"Wahai orang-orang yang beriman! Janganlah suatu kaum mengolok-olok kaum yang lain, (karena) boleh jadi mereka (yang diperolok-olokan) lebih baik dari mereka (yang mengolok-olok), dan jangan pula perempuan-perempuan (mengolokolokan) perempuan lain, (karena) boleh jadi perempuan (yang diolok- olokan) lebih baik dari pada perempuan (yang mengolok-olokan), janganlah kamu saling mencela satu sama lain, dan janganlah saling memanggil dengan gelar-gelar yang buruk. Seburuk-buruk panggilan adalah (panggilan) yang buruk

${ }^{13} \mathrm{KH}$. Nasaruddin Umar saat menjelaskan bahaya hate speech atau ujaran kebencian dalam acara kongres ke-17 Muslimat Nahdatul Ulama Komisi Batshul Masa'il 
(fasik) setelah beriman, dan barang siapa tidak bertaubat, maka mereka itulah orang-orang yang zalim" (Q.S. Al-Hujurat [49]:11)14

Ayat ini menerangkan bahwa, Allah SWT memperingatkan kaum mukmin supaya jangan ada suatu kaum mengolok-olokan kaum yang lain, karena boleh jadi, mereka yang memperolok-olokkan itu lebih buruk daripada mereka yang diperolok-olokkan, dan demikian pula di kalangan wanita, janganlah ada segolongan wanita yang meperolok-olokkan wanita lain, karena bisa jadi wanita yang memperolok-olokkan itu lebih buruk daripada wanita yang diperolokolokkan.

Allah SWT melarang pula kaum mukminin untuk mencela kaum mereka sendiri, karena kaum mukminin semuanya harus dipandang satu tubuh yang diikat dengan kesatuan dan persatuan, dan dilarang pula memanggil dengan panggilan- panggilan atau gelar yang buruk seperti panggilan kepada seseorang yang sudah beriman dengan kata-kata: "hai fasik", "hai kafir" dan sebagainya. Ayat ini juga menerangkan bahwa Allah SWT menjelaskan adab-adab (pekerti) yang harus berlaku diantara sesama mukmin, dan juga menjelaskan beberapa fakta yang menambah kadar persatuan umat Islam, yaitu : a) Menjauhkan diri dari berburuk sangka kepada yang lain, b) Menahan diri dari memata-matai aib orang lain; dan c) Menahan diri dari mencela dan menggunjing orang lain. ${ }^{15}$

Ayat ini dijadikan oleh Allah SWT sebagai peringatan dan nasehat untuk kita bersikap lemah lembut dan sopan santu dalam kehidupan. Rasulullah SAW juga menegaskan dalam haditsnya yang diriwayatkan oleh Abu Hurairah, sebagai berikut:

"Dari Abu Hurairah Rhadiyallahu 'anhu, dari Rasulullah Shallallahu 'alaihi wa sallam, beliau bersabda: Barang siapa yang beriman kepada Allah SWT dan hari akhir, maka berikanlah pernyataan yang baik atau lebih baik diam" (HR. Bukhari dan Muslim)

Rujukan dari kedua dalil Al-Qur'an dan Hadits ini, bahwa jelas Islam melarang perbuatan menghina atau menghasut kepada sesama manusia, walaupun medianya dimana saja baik itu di ruang hlm 516

${ }^{14}$ Al-Qur'an dengan Tajwid Blok Warna diserta terjemahan, (Jakarta: Lautan Lestari, 2010),

${ }^{15}$ Abdul Malik Abdul Karim Amrullah (HAMKA), Tafsir al-Ashhar, (Surabaya, Yayasan Nurul Islam, 1982), hlm. 236 
publik, media sosial, terlebih secara langsung. Demikan bahwa ujaran kebencian (hate speech) itu erat kaitannya dengan menjaga kehormatan dalam Islam.

Oleh karena itu, setiap orang wajib untuk memelihara dan menjaga kehormatan diri sendiri dan orang lain. Karena hal tersebut dapat menimbulkan rasa ketenangan dan ketentraman bagi masyarakat, sebagaimana yang dikehendaki oleh Islam. Islam mengajarkan kepada penganutnya agar berbahasa, berperilaku, bertutur kata, baik secara lisan maupun tulisan dengan baik, sesuai dengan tujuan dari pada syariat Islam itu sendiri, yang dikenal dengan istilah al-maqashid al- syari'ah, guna mencapai kemaslahatan ummat.

\section{Klasifikasi Tindak Pidana Ujaran Kebencian (Hate Speech) dalam Hukum Pidana Islam}

Tindak pidana (jarimah) dalam hukum pidana Islam membagi menjadi beberapa macam jenis, sesuai dengan aspek yang ditonjolkan. Pada umumnya para ulama membagi tindak pidana (jarimah) berdasarkan aspek berat dan ringannya hukuman serta ditegaskan atau tidaknya oleh Al-Qur'an atau Hadits. Atas dasar ini, para ulama membaginya menjadi tiga macam yaitu: jarimah hudud, jarimah qishahs-diyat, danjarimah ta'zir.

a. Jarimah Hudud, Jarimah hudud, yaitu kejahatan yang diancam dengan hukuman had (yaitu hukuman yang ditentukan kadarnya sebagai hak Allah SWT), dalam defenisi ini, "hukuman yang ditentukan" berarti bahwa baik kualitas, maupun kuantitasnya ditentukan, dan tidak mengenal tingkatan. Lebih lanjut jarimah hudud ini meliputi: perzinahan, qadzaf (menuduh zina), minum khamr (meminum minuman keras), pencurian, perampokan, pemberontakan, dan murtad.

b. Jarimah Qishasd/Diyat, Kategori Jarimah qishash/diyat. Ia jatuh pada posisi di tengah antara jarimah hudud dengan jarimah ta'zir dalam hal beratnya. Kejahatan-kejahatan dalam kategori Qishahs/diyat ini kurang serius dibandingkan dengan kategori hudud, namun lebih berat daripada yang berikutnya (ta'zir). Sasaran dari kejahatan ini adalah integritas tubuh manusia, senagaj atau tidak sengaja, ia terdiri dari apa 
yang dikenal dalam hukum pidana modern sebagai "kejahatan terhadap manusia/crimes againt's persons". Jarimah qishash/diyat ini meliputi: pembunuhan sengaja, pembunuhan serupa sengaja, pembunuhan tidak sengaja, penganiayaan sengaja, dan penganiayaan tidak sengaja. Imam Malik membagi pembunuhan menjadi dua macam, yaitu pembunuhan sengaja dan pembunuhan karena kesalahan. Alasannya, Al-Qur'an hanya mengenal kedua jenis jarimah tersebut.

c. Jarimah Ta'zir, Istilah jarimah ta'zir menurut hukum pidana Islam adalah tindakan yang berupa edukatif terhadap pelaku perbuatan dosa yang tidak ada sanksi had dan kifaratnya. Dengan kata lain, ta'zir merupakan hukuman terhadap perbuatan pidana / delik yang tidak ada ketetapan dalam nash hukumannya. Hukuman-hukuman ta'zir tidak mempunyai batas-batas tertentu, karena syara' hanya menyebutkan sekumpulan hukuman, mulai dari seringan-ringannya sampai kepada hukuman yang paling berat, dengan kata lain, hakim yang berhak menentukan macam tindak pidana beserta hukumannya, karena kepastian hukumnya belum ditentukan oleh syara.

Jarimah ta'zir terbagi menajdi tiga bagian:

1) Jarimah hudud atau qishash/diyat yang subhat atau tidak memenuhi syarat, unsur dari tindak pidana, namun sudah merupakan maksiat. Misalnya, percobaan pencurian, percobaan pembunuhan, pencurian di kalangan keluarga, dan pencurian aliran listrik.

2) Jarimah-jarimah yang ditentukan oleh Al-Qur'an dan Hadits, namun tidak ditentukan sanksinya. Misalnya, penghinaan, saksi palsu, tidak melaksanakan amanah, dan menghina agama.

3) Jarimah-jarimah yang ditentukan oleh ulul amri untuk kemaslahatan umum. Dalam hal ini, nilai ajaran agama Islam dijadikan pertimbangan dalam menentukan kemaslahatan umum. Persyaratan kemaslahatan ini secara rinci diuraikan dalam bidang studi ushul fiqh. Misalnya, pelanggaran lalu lintas.

Jenis tindak pidana ta'zir tidak hanya terbatas pada macammacam tindak pidana sebagaimana di atas, Jarimah ta'zir sangat luas dan elastis, sehingga perbuatan apapun (selain daripada jarimah 
hudud dan qishash/diyat) yang menyebabkan pelanggaran terhadap agama, atau terhadap penguasa, atau terhadap masyarakat, atau terhadap perorangan, maka dapat dikategorikan sebagai jarimah ta'zir.

Tindak pidana ujaran kebencian (hate speech) dalam ketiga klasifikasi tindak pidana (jarimah) di atas masuk ke dalam klasifikasi jarimah ta'zir yang berkaitan dengan kejahatan kehormatan dan kerusakan akhlak, karena perbuatan ujaran kebencian (hate speech) tidak ditentukan atau tidak terdapat dalam kategori jarimah hudud ataupun qishash/diyat, sehingga merupakan lingkup dari jarimah ta'zir. Perbuatan ujaran kebencian (hate speech) merupakan perbuatan yang menyangkut dengan kehormatan atau nama baik dari seseorang. Perbuatan ujaran kebencian (hate speech) dengan jarimah qadzaf dalam klasifikasi jarimah hudud sama, yaitu sama-sama menyangkut dengan kehormatan dan nama baik seseorang. Namun, perbuatan ujaran kebencian (hate speech) ini tidak dapat dihukum dengan hukuman qadzaf, hal ini dikarenakan bahwa qadzaf merupakan hukuman yang sudah Allah SWT tetapkan rukun dan syarat yang menjadikan unsur dari suatu tindak pidana (jarimah), sehingga apabila rukun dan syarat itu tidak terpenuhi maka bukan bagian dari jarimah qadzaf dan tidak pula dihukum dengan jarimah qadzaf.

Unsur-unsur perbuatan ujaran kebencian (hate speech) dilihat dari unsur- unsur tindak pidana dalam hukum pidana Islam adalah sebagai berikut:

1) Rukun Syar'i (Unsur Formil)

Unsur formil adalah adanya ketentuan syara' atau nash yang menyatakan bahwa perbuatan yang dilakukan merupakan perbuatan yang dilarang atau dapat dijatuhi hukuman. Dasar larangan perbuatan yang berhubungan dengan penyebaran ujaran kebencian (hate speech) adalah sebagai berikut:

a) Al-Qur'an Surah al-Hujurat ayat 11

"Hai orang-orang yang beriman, janganlah sekumpulan orang laki-laki merendahkan kumpulan yang lain, boleh jadi yang ditertawakan itu lebih baik dari mereka. Dan jangan pula sekumpulan perempuan merendahkan kumpulan lainnya, boleh jadi yang direndahkan itu lebih baik. Dan janganlah suka mencela dirimu sendiri dan jangan memanggil dengan gelaran yang mengandung ejekan. 
Seburuk-buruk panggilan adalah (panggilan) yang buruk sesudah iman dan barangsiapa yang tidak bertobat, maka mereka itulah orang-orang yang zalim" (Al-Hujurat: 11).

b) Al-Qur'an Surah Al-Hujurat ayat 12

"Hai orang-orang yang beriman, jauhilah kebanyakan purba-sangka (kecurigaan), karena sebagian dari purbasangka itu dosa. Dan janganlah mencari-cari keburukan orang dan janganlah menggunjingkan satu sama lain. Adakah seorang diantara kamu yang suka memakan daging saudaranya yang sudah mati? Maka tentulah kamu merasa jijik kepadanya. Dan bertakwalah kepada Allah. Sesungguhnya Allah Maha Penerima Taubat lagi Maha Penyayang' (Q.SAl-Hujurat:12)

\section{Rukun Al-Maddi (Unsur Materil)}

Unsur materil, yaitu adanya perilaku yang membentuk jarimah atau tindak pidana, baik berupa perbuatan ataupun tidak berbuat atau adanya perbuatan yang bersifat melawan hukum, dalam hal ini penyebaran ujaran kebencian merupakan perbuatan yang bertentangan dengan anjuran syari'at Islam, sehinggan perbuatan penyebaran ujaran kebencian merupakan perbuatan yang melawan hukum.

3. Rukun Al-Adabi (Unsur Moral)

Unsur moral, maksudnya pelaku penyebaran ujaran kebencian harus dapat mempertanggungjawabkan perbuatannya, orang yang dianggap dapat mempertanggungjawabkan perbuatannya yaitu orang yang sudah cakap hukum atau mukallaf.

\section{Sanksi Tindak Pidana Ujaran Kebencian (HateSpeech)}

Atas perbuatan ujaran kebencian (hate speech), jika dilihat dari macam-macam sanksi ta'zir sebagaimana yang telah dijelaskan di atas, maka penjatuhan sanksi bagi pelaku penyebaran ujaran kebencian (hate speech) tergantung kepada kemaslahatan ummat. Karena penjatuhan sanksi ta'zir didasarkan atas kemaslahatan. Sanksi ta'zir yang terberat adalah hukuman mati, sedangkan sanksi yang teringan adalah hukuman peringatan. Berat ringannya sanksi ta'zir ditentukan kemaslahatan. Dalam hal ini harus dipertimbangkan 
perbuatannya, baik kulaitas maupun kuantitas, pelakunya, orang atau masyarakat yang jadi korbannya, tempat kejadian dan waktunya, mengapa dan bagaimana si pelaku melakukan kejahatan. ${ }^{16}$

Sesuai dengan kaidah fiqh yang mengatakan "sanksi ta'zir (berat-ringannya) bergantung kepada kemaslahatan". Juga kaidah yang berbunyi "berat ringannya sanksi ta'zir diserahkan kepada Imam (hakim) sesuai dengan besar kecilnya kejahatan yang dilakukan". Kaidah ini memberi kewenangan kepada hakim dalam menjatuhkan berat-ringannya hukuman. Sudah barang tentu, penjatuhan sanksi harus mempertimbangkan daya preventif dan refresifnya (al-radd' wa al-jazr) dari hukuman tersebut, serta daya edukatif dan rehabilitatif bagi yang bersangkutan.

Diketahui bahwa dalam mengambil sebuah keputusan, tentunya hakim juga harus selalu berpedoman kepada asas-asas yang sudah ditetapkan dalam hukum pidana Islam, seperti asas keadilan (proporsional), asas kepastian hukum (sesuai dengan anjuran syari'ah) serta asas kemanfaatan dalam penjatuhan hukuman (melihat dari segi manfaat dan madharat nya). Hal tersebut bertujuan agar terjadi keadilan dalam menetapkan sebuah hukuman atau sanksi, baik berupa hukuman badan, hukuman yang berkaitan dengan kemerdekaan, hukuman yang berkaitan dengan harta, ataupun hukuman dalam bentuk lain, seperti misalnya teguran dan peringatan.

Penanganan sebelum mengarah kepada penjatuhan hukuman dalam hukum pidana Islam terdapat kesamaan dengan hukum positif Indonesia, yakni pemberian tindakan pencegahan orang lain agar tidak melakukan jarimah dan membuat pelaku jera sehingga tidak akan mengulangi perbuatan yang sama. Akan tetapi dalam hukum pidana Islam ditambah dengan sikap pengajaran dan pendidikan sehingga diharapkan dapat memperbaiki diri pelaku jarimah. Apabila kegiatan pencegahan telah dilakukan namun pelaku penyebaran ujaran kebencian (hate speech) tidak jera, maka hakim dapat melakukan penjatuhan hukuman atau sanksi yang telah ditetapkan dalam ta'zir.

Penjatuhan hukuman bagi pelaku pencemaran nama baik sangat penting dalam hukum Pidana Islam, karena dalam hukum pidana Islam mempunyai tujuan utama dalam pembentukan hukum, yaitu untuk kemaslahatan umat manusia, baik di dunia maupun di akhirat. Hal ini 
dikenal dengan al-Maqasida asy-Syari'ah atau tujuan hukum Islam: hifz al-Nasl (menjaga jiwa), hifz al-'Aql (menjaga akal), hifz al-Din (menjaga agama), hifz al-Mal (menjaga harta) dan hifz al-Nasl (menjaga keturunan).

Indonesia sebagai Negara yang penduduknya mayoritas beragama Islam tentu memiliki peraturan yang mengharamkan perbuatan penyebaran ujaran kebencian (hate speech) sebagai bentuk larangan yang ditetapkan oleh ulil amri (penguasa) untuk tidak dilaksanakan, larangan tersebut terdapat dalam Fatwa Majelis Ulama Indonesia yang menyebutkan bahwa, setiap muslim yang bermuamalah melalui media sosial diharamkan untuk melakukan bullying, ujaran kebencian, dan permusuhan atas dasar suku, agama, ras, atau antar golongan. ${ }^{17}$

Ancaman sanksi sebagaimana yang tertuang dalam Pasal 45 ayat (2) UU ITE yang mengancam pelaku penyebaran ujaran kebencian dengan ancaman hukuman penjara paling lama 6 (enam) tahun dan/atau denda paling banyak Rp 1.000.000.000.00 (satu miliar rupiah) tidak bertentangan dengan syari'at Islam, karena pemenjaraan juga merupakan salah satu bentuk dari sanksi ta'zir yang diharapkan dapat memberikan efek jera bagi pelaku agar tidak melakukan perbuatan jarimah atau tindak pidana penyebaran ujaran kebencian(hate speech).

\section{Relevansi Tindak Pidana Ujaran Kebencian (Hate Speech) dalam Hukum Pidana Islam dengan UU ITE}

Relevansi tindak pidana penyebaran ujaran kebencian (hate speech) dalam hukum pidana Islam dengan Pasal 28 ayat (2) Jo Pasal 45 ayat (2) UU ITE, dibedakan dari beberapa segi, yaitu:

1. Segi klasifikasi tindak pidana ujaran Kebencian (hate speech). Unsurunsur tindak pidana ujaran kebencian menurut UU ITE Pasal 28 ayat (2), yaitu:

a. Unsur objektif 18 :

\footnotetext{
${ }^{17}$ Fatwa Majelis Ulama Indonesi Nomor 24 Tahun 2017 tentang Hukum dan Pedoman Bermuamalah melalui Media Sosial, hlm.14

18 Unsur objektif merupakan unsur dari luar diri si pelaku yang terdiri atas perbuatan manusia, akibat perbuatan manusia, keadaan-keadaan, dan sifat dapat dihukum serta sifat melawan hukum. Semua unsur delik tersebut merupakan satu kesatuan, yang mana salah satu
} 
Menyebarkan Informasi;

1) Yang ditujukan untuk menimbulkan kebencian atau permusuhan;

2) Terhadap seseorang dan/atau sekelompok orang;

3) Berdasarkan atas suku, agama, ras dan antar golongan.

b. Unsur subjektif 19 :

1) Dengan sengaja

2) Tanpak hak

Penyebaran ujaran kebencian (hate speech) dalam UU ITE merupakan perbuatan yang tergolong ke dalam tindak pidana terhadap kehormatan, istilah lain yang juga umum dipergunakan untuk tindak pidana terhadap kehormatan adalah tindak pidana penghinaan. Dipandang dari sisi sasaran atau objek delicti, yang merupakan maksud atau tujuan dari Pasal tersebut yakni melindungi kehormatan, maka tindak pidana terhadap kehormatan lebih tepat, pembentuk undang-undang juga sejak semula bermaksud melindungi kehormatan (eer) dan nama baik (geode naam).

Penyebaran ujaran kebencian (hate speech) dalam hukum pidana Islam, merupakan perbuatan yang menyangkut dengan kehormatan atau nama baik dari seseorang, yaitu berupa penghinaan, pencemaran nama baik, mencaci maki, menggunjing, dan sebagainya yang menyebabkan timbul rasa kebencian atau permusuhan terhadap seseorang. Oleh karena itu, perbuatan ujaran kebencian (hate speech) masuk dalam klasifikasi ta'zir dalam kategori jarimah yang ditentukan oleh Al-Qur'an dan Hadits.

\section{Simpulan}

Pengaturan ujaran kebencian tertuang dalam Pasal 28 ayat (2) Jo Pasal 45 ayat (2) UU ITE. Pasal ini memuat unsur objektif dan subjektif, jenis delik ini termasuk ke dalam delik formil, delik yang dianggap sebagai delik dengan melanggar undang-undang, dalam arti lain tidak memerlukan adanya akibat dari perbuatan tersebut, dan

unsur saja tidak terpenuhi atau tidak terbukti, bias menyebabkan pelaku dibebaskan pengadilan. Ledeng Marpaung, Asas-Asas Hukum Pidana, (Jakarta: Sinar Grafika, 2005), hlm. 107

${ }^{19}$ Unsur subjektif adala unsur yang berasal dari dalam diri si pelaku. Asas hukum pidana menyatakan "tidak ada hukuman kalau tidak ada kesalahan". Kesalahan yang dimaksud disini adalag kesalahan yang diakibatkan oleh kesengajaan dan kealpaan. Ledeng Marpaung Asas-Asas Hukum Pidana, (Jakarta: Sinar Grafika, 2005), hlm. 107 
tindak pidana ujaran kebencian termasuk kedalam tindak pidana yang berhubungan dengan kehormatan/nama baik seseorang.

Tinjauan hukum pidana Islam terhadap tindak pidana ujaran kebencian termasuk ke dalam kategori jarimah ta'zir, Jarimah ta'zir yang berkaitan dengan kejahatan terhadap kehormatan atau kerusakan akhlak, yang pelakunya akan dikenakan sanksi ta'zir dari ancaman paling berat sampai kepada hukuman yang terendah, penjatuhan sanksi berdasarkan kemaslahatan ummat.

Relevansi tindak pidana penyebaran ujaran kebencian dalam hukum pidana Islam dengan UU ITE, yaitu dari segi pengklasifikasian delik, yaitu sama-sama mengklasifikasikan tindak pidana yang berhubungan dengan kehormatan/nama baik seseorang, dan dari segi sanksi, yaitu sama-sama menetapkan hukuman paling berat dan paling ringan.

\section{DAFTAR PUSTAKA}

Abdul Hamid Al-Ghazali, Ihyaul Ulumuddin, (Ciputat: Lentera Hati, 2003) Abdul Malik Abdul Karim Amrullah (HAMKA), Tafsir al-Ashhar, (Surabaya, Yayasan Nurul Islam, 1982)

Al-Qur'an dengan Tajwid Blok Warna diserta terjemahan, (Jakarta: Lautan lestari, 2010).

Al-Qur'an dengan Tajwid Blok Warna diserta terjemahan, Jakarta: Lautan Lestari, 2010

Al-Qur'an dengan Tajwid Blok Warna diserta terjemahan, 2010, Op.Cit.

Budi Suhariyanto, Tindak Pidana Teknologi Informasi (CYBERCRIME),

(Jakarta: PT. Raja Grafindo Persada, 2014)

Ledeng Marpaung, Asas-Asas Hukum Pidana, Jakarta: Sinar Grafika, 2005

M. Nurul Irfan \& Masyrofah, Fiqh Jinayah, Jakarta: AMZAH, 2013,

Moeljatno, Kitab Undang-Undang Hukum Pidana (KUHP), Jakarta: Bumi Aksara, 2014

Soerjono Soekanto, Pokok-Pokok Sosiologi Hukum, Jakarta: PT Raja Grafindo Persada, 2001

Sutan Remy Syahdeini, Kejahatan dan Tindak Pidana Komputer, (Jakarta: Pustaka Utama Grafiti, 2009

Undang-Undang R.I. No. 11 Tahun 2008 Tentang Informasi dan Data Transaksi Elektronik, (Yogjakarta: Pustaka Mahardika)

Zainuddi Ali, Hukum Pidana Islam, Jakarta; Sinar Grafika, 2007 
Zainudin Hasibuan: Tinjauan Hukum Pidana Islam tentang Ujaran Kebencian... | 203

Fatwa Majelis Ulama Indonesi Nomor 24 Tahun 2017 tentang Hukum dan Pedoman Bermuamalah melalui Media Sosial

KH. Nasaruddin Umar saat menjelaskan bahaya hate speech atau ujaran kebencian dalam acara kongres ke-17 Muslimat Nahdatul Ulama Komisi Batshul Masa'il 